\title{
Kieran Walsh, Gemma M. Carney and Áine Ní Léime (eds.) (2015). Ageing through Austerity: Critical Perspectives from Ireland. Bristol, UK: Policy Press, 196 pp. ISBN 9781447316237 (hardback)
}

\author{
REVIEWED by FRANCESCO BARBABELLA*
}

It is widely known that social policies in most part of Europe have been deeply affected, in the last decade, by a series of austerity measures put in place by policy makers in order to comply with the new goals of optimising public resources and cutting welfare expenditure where they were seen as too generous. The recession experienced by many countries in Europe, after the start of the economic crisis in 2008, accelerated and exacerbated some international policy trends, claiming for more control over the raising welfare state costs and more limitation of public intervention. As the portion of welfare resources absorbed by pension, health and social care policies for older people was highly significant in all European countries, it was a natural consequence that austerity would have put the social protection system around older people under pressure.

Despite these facts, there are not yet enough knowledge and evidence around how austerity policies produced an impact on the well-being of older people and also future cohorts. The book Ageing through Austerity: Critical Perspectives from Ireland aims to fill this gap and elaborates critical

* Francesco Barbabella, Department of Health and Caring Sciences, Linnaeus University, Kalmar, Sweden; Centre for Socio-Economic Research on Ageing, National Institute of Health and Science on Ageing (INRCA), Ancona, Italy 
International Journal of Ageing and Later Life

issues on social changes occurring in last few years in Ireland. Kieran Walsh, Gemma M. Carney and Áine Ní Léime are the editors of this collection of studies carried out by an interdisciplinary team of researchers from the Irish Centre for Social Gerontology at the National University of Ireland (NUI), Galway. The contributors analyse, discuss and point out the current trends and implications over a wide range of social policy areas. Authors adopted the perspective of critical gerontology, applied through a variety of methodologies and disciplines, to analyse and evaluate the case of Ireland. Through this perspective, ageing is studied as a social construction, with the social policy system investigated as the "primary mechanism in creating current and future experiences of ageing" (Walsh et al. 2015: 5).

This book is composed of nine chapters. Chapter 1 constitutes an introduction to the work provided by the editors and explains the relevance of the research on austerity, especially in Ireland where the ageing policy development seems mainly characterised - despite some symbolic concessions - by indifference and "continuity of ineffectual sameness" (Walsh et al. 2015: 13). The demographic and socio-economic peculiarities of Ireland are also described in brief in order to give some contextual details, and research objectives are explicated, including the ambition to search for possible implications and generalisations of results for other countries.

Most of the following chapters present a similar structure, starting with a review of the literature around the social policy issue, the evidence emerging from the Irish context and, finally, the discussion of policy and research issues for going beyond the findings. Chapter 2, written by Sheelah Connolly, concerns a more in-depth contextualisation of ageing in Ireland. It sketches a demographic, socio-economic and health portrait of older people, describing the layers of dedicated welfare measures (pensions, health and social care) and the recent policy decisions leading to significant cuts in public budgets. In her conclusions, she questions the belief that older people in Ireland have only been marginally affected by cuts, pointing out the heterogeneity of this target group and the risk of cumulative disadvantages.

Chapter 3 is authored by Gemma Carney and provides insights on the implications of demographic ageing for social citizenship. From a political perspective, she discusses the intersection of democratisation and 
Ageing through austerity. Book review

globalisation of ageing societies and their impact on older people's political activity and involvement in social rights movements. It is noted how a suggestion to cut of the state pension was blocked in 2008 after mass protests. These protests were heavily supported by Irish society, while similar cuts in child benefits and disability services did not lead to similar broad protests. Such differences were explained by the high level of social cohesion on this issue, sustained by family solidarity and desire to keep pensioners' conditions on current, decent levels.

Chapter 4 focuses on the issue of active ageing, including the key questions of the consequences of being socially excluded from active ageing but also contributing to the labour market in older age. The two authors, Áine Ní Léime and Sheelah Connolly, define the concept of active ageing and discuss conditions, impacts and barriers of participation. Final conclusions consider the underdevelopment of research on the link between active ageing and austerity, and also that the lack of priority in policy programmes started well before the occurrence of the recession.

Gender inequalities are the central topic of Chapter 5, by Áine Ní Léime, Nata Duvvury and Aoife Callan. They explore the gender issue in the pension system in Ireland, trying to understand how the traditional "male breadwinner" model has been actually reinforced by austerity reforms of the pension policy. Authors adopted "a life-course approach with a feminist political-economy-of-ageing approach" (p. 5) for investigating the topic. The drawn conclusions are that women are and will remain more disadvantaged in terms of pensions, especially those with precarious employments.

In Chapter 6, Kieran Walsh questions the concept of age-friendly communities and aims to understand the relationship of older people with their place and community. The concept of age-friendly community, promoted by the World Health Organization (WHO), has found fertile ground in Ireland. However, recession and austerity had some negative impact on the linkages between some groups of older people and their communities, as well as on the sustainability of the programmes themselves.

Chapter 7 is dedicated to policy and service framework of dementia care in Ireland, also in comparison with some international examples. Eamon O'Shea, Suzanne Cahill and Maria Pierce explain that there are around 30,000 older people with dementia living at home in the country, some 
International Journal of Ageing and Later Life

without a formal diagnosis, with the network of services challenged by low resources and a high pressure put over family carers' shoulders. The conclusions call for considering dementia as a priority for stakeholders and policy makers in order to improve societal attitudes and care services for people affected.

Chapter 8 is authored by Thomas Scharf and focuses on patterns of social inclusion and exclusion in later life. This chapter has a twofold aim: to review the international works on the different types of social exclusion for ageing adults and to present key evidence on the forms of exclusion experienced by older people in Ireland. Poverty and material deprivation, loneliness and isolation, exclusion from civic activities, formal services and community are the core dimensions investigated by Scharf. He claims that, despite other views, older people were affected by the economic crisis, with increasing risks of social exclusion under many aspects.

The final chapter constitutes a series of overarching conclusion drawn by Gemma Carney, Kieran Walsh and Áine Ní Léime, also including methodological, theoretical and critical issues for social policy in Ireland and beyond in relation to ageing and austerity. To give even more substance to the whole work, the book is accompanied by further reflections of two highly respected scholars, Alan Walker and Chris Phillipson, who wrote, respectively, the foreword and afterword.

Overall, the book is a good tool for breaking the ice and initiating an evidence-based, open discussion on the effects of austerity measures - not only for Ireland but for the whole European context - in a various range of intersections with issues of social policy, active ageing, social exclusion and inequalities, services and community. The book shows that austerity measures did have an impact on the older population in Ireland, particularly visible for those segments more at risk of social exclusion and who experience cumulative social disadvantages. A series of health and social programmes restricted their scope and users, like for services for dementia care and local age-friendly community initiatives. The societal resilience to the introduction of austerity measures was based on a strong social cohesion and re-activated mechanisms of informal support networks and family care. Such resilience, however, is putting families under severe pressure and seems not to be understood enough at policy level, where ageing is no longer a priority in the agenda. 
The book highlights well the current implications and provides some reflections on what will happen next for new cohorts of older people. A more in-depth perspective on the future perspective of older people is partly missing in this collection of studies. In fact, since many of the adopted policy measures have become structural changes de facto, it is crucial to understand now their possible medium- and long-term impact on society. A focus on the ageing process and the life-course would support current concerns over social changes and project them in future implications and related counter-actions to propose and discuss, in both scientific and policy communities. In the end, the book should be seen as a first exploration of an under-investigated area and offers relevant inputs for continuing research in this direction in Ireland and Europe.

\section{Reference}

Walsh, K., Carney, G. \& Ní Léime, A. (2015). Introduction - Social policy and ageing through austerity. In Kieran Walsh, Gemma Carney \& Áine Ní Léime (eds.), Ageing through Austerity: Critical Perspectives from Ireland (pp. 1-16). Bristol: Policy Press. 